\title{
The Experience of Assessing Out-of-School Learning Environments
}

\author{
Halit Kiriktaş ${ }^{*}$, Sinan Eslek \\ Department of Science Education, Dokuz Eylül, University, İzmir, Turkey
}

Copyright $\subset 2017$ by authors, all rights reserved. Authors agree that this article remains permanently open access under the terms of the Creative Commons Attribution License 4.0 International License

\begin{abstract}
This study aimed to investigate out-of-school learning environments within the borders of the province of İzmir in terms of various parameters. With this purpose, the researchers developed "the Out-Of-School Learning Environments Assessment Survey." The study used the screening model, which is a descriptive research method. In the scope of this study, a total of 13 out-of-school learning environments in İzmir were investigated. These included the Young Explorers Center for Science, the Mevlana Center for Science, the Ödemiş Center for Science, Karşıyaka Museum of Science, İzmir Museum of Archeology, Museum of Ethnography, İnciraltı Naval Museum, Arkas Museum of Art, Selçuk Urban Memory, the Ancient City of Efes, Ege University Botanical Garden, and Sasalı Wild Life Park. As a result of statistical operations based on the calculation of frequencies and percentages on the obtained data, it was found that, among the designed out-of-school learning environments in the samples, centers for science satisfied the criteria expected to be determined by the survey to a certain extent, museum groups were "very inadequate" regarding desired qualities, and the levels of satisfaction of expectations for other environments had "acceptable" standards.
\end{abstract}

Keywords Science Education, Out-of-School Learning, Life-long Education, Center for Science

\section{Introduction}

It may be stated that the learning process defined as the changes in behavior as a result of individuals' experiences of their environment is based on 4 main elements. These are the individual who actively participates in the learning process and facilitates learning, the teacher who acts as a guide to make the learning process easier and more meaningful, the teaching plan followed during the learning process, and the (social and physical) environment where learning takes place $[13,15,42]$. The characteristics that the individual, who is in the center of the process of learning, holds before the process (readiness, physiological and psychological traits) and the performance they show during the process, affect the meaningfulness and permanence of learning directly. On the other hand, the qualifications of the teacher who is the guide of the process (knowledge of the field, pedagogical knowledge, knowledge of instruction technology, etc.) and the route the teacher follows in the process are as effective as the individual on the meaningfulness and permanence of learning.

In addition to these, realization of an effective and permanent learning process is also highly affected by the social structure and physical conditions of the environment where learning will take place, its suitable design for the process of teaching and learning, and presence of structures and elements in this environment $[15,19,33]$.

Based on the literature review, it may be seen that the learning process shaped over the 4 elements mentioned above is categorized in different ways based on the effectiveness, characteristics of these main elements, and the environment where learning takes place $[1,2]$. One of these categorization is categorization based on the environment of learning and whether the process is dependent on a certain plan or not. In this approach, learning is considered under 3 sub-groups as "formal learning" (structured), "informal learning" (semi-structured) and "non-formal learning" (non-structured) [1, 12, 37, 38]. While formal (structured) learning is defined as types of learning that take place in the school environment under the supervision of teachers based on a certain plan [13,43]; informal (semi-structured) learning is defined as a process that takes place in like by itself, where individuals join the process due to their own interests and wishes, without being dependent on a teacher or a plan, and progresses through life and along the depth of life $[1,37,38]$. While non-formal (non-structured) learning is not structured from end to end for a diploma or a certificate program, it is learning that takes place under supervision of an expert of a subject, or a person who is experienced in a subject $[1,9,37]$.

On the other hand, it may be noticed that these types of 
learning are defined differently in OECD (Organization for Economic Cooperation and Development) reports. While the OECD defines formal learning as "the learning process carried out in presence of a supervisor dependent on a structured plan," it defines informal learning as non-structured learning, and non-formal learning as semi-structured learning [35].

While the literature points to differences in defining these types of learning, it may be seen that there is a consensus regarding the characteristics (advantage - shortcomings) of learning environments that are formal. It is reported that out-of-school learning processes (informal and non-formal learning) occur in line with the interests and wishes of individuals, and the individual follows the process with high motivation. Again, it is stated that knowledge is structured in a natural environment with active participation of the individual, and therefore, these are more meaningful and permanent than learning processes in formal environments [28]. Additionally, it is also indicated that formal learning takes place in a certain period and within some limits (within a plan), while out-of-school learning takes place life-long, life-deep and life-wide, and it thus provides a more meaningful and permanent learning opportunity of than formal learning. On the other hand, it is reported that running and evaluating out-of-school learning processes, and inspecting the suitability of information gained from such environments for scientific knowledge are hard, and it is more difficult than it is in formal learning to prepare and present outcomes and content as they should appeal to all age groups $[1,7,16,21,35,37,38]$.

The literature reports the shortcomings and difficulties in practice regarding out-of-school learning environments, but it may be seen that there are not many studies on how to overcome these difficulties and eliminate these shortcomings. The out-of-school learning process and the elements forming the process (individual, teacher, plant and learning environment) should be analyzed correctly in the process of eliminating the shortcomings and overcoming the difficulties mentioned above. In the process of out-of-school learning, participants may be from all ages, all social classes and levels of education. This makes it impossible to determine the readiness levels of individuals regarding the subjects or organize the process based on interests and wishes of individuals. Based on this, it does not seem possible to design, implement and evaluate the process of out-of-school learning with the individual in the center.

Additionally, as the process is carried out independently of a plan and the teacher is only a guide (in a more passive position than that in the formal learning process), it becomes impossible to structure out-of-school learning processes based on these elements.

Designing, implementing and evaluating the process of out-of-school learning is seen possible only by designing the learning environment which is prepared towards certain outcomes with all of its aspects (content, design, physical conditions, etc.) in a way suitable for the learning and teaching process. In this context, the framework of out-of-school learning will be drawn by preparing the content (activities, experiments and other applications) of the environment in a was suitable for scientific knowledge, using appropriate methods. Likewise techniques in presentation of content, designing the environment where the process is carried out in a way that is suitable for teaching activities in terms of physical conditions, and shaping the environment in the light of the approach of constructivist learning will constitute criteria at this topic.

A learning environment which is suitable for constructivist paradigm may be defined as a learning environment that presents and authentic problem to the individual taking part in the process, expects solution of the problem by usage of high level cognitive skills. Besides The learning environment should provide to learners stimulates preliminary knowledge and experiences, prioritizes questioning and scientific debate, allows individuals to freely express their thoughts and opinions, discusses a sufficient number of concepts in detail based on the available time, and builds skills of technology usage, where the individual structures knowledge via active participation [16, 22]. In this case, an implicit learning environment will take form by design of the environment in compliance with the characteristics in question. Accordingly, as appropriate for the nature of out-of-school learning, individuals will participate in the process due to their own interests and wishes, and follow the process with high levels of motivation. Knowledge will be presented to the individuals in its natural environment, and meaningful and permanent learning will occur. Furthermore, misconceptions and reception of incorrect information will be prevented by presentation of content prepared suitably for scientific approach with appropriate methods and techniques.

Understanding that learning occurs permanently, effectively and scientifically in the out-of-school learning environment may be possible through; the type of learning environment (museum, center for science, etc.) and sufficiency of activities in the environment in terms of meaningful learning (interactive and open-ended), suitability of the learning environment and activities in this environment for constructivist paradigm, its suitability for criteria expected from learning environments (6 strands reported by the National Science Foundation - NSF), physical suitability of the environment for the teaching process, and suitability of the environment for fields of learning.

The literature review shows that there are domestic and international studies that discuss types of out-of-school learning (informal and non-formal) in various aspects, but are mainly on determining the participant behavior in out-of-school learning processes and investigating the effects of these processes on various parameters (academic success, critical thinking, attention, motivation, etc.) $[4,11,24,25$, $27,36,39,44]$. On the other hand, no studies were found to be related to the ways to design, implement and evaluate 
out-of-school learning environments, or characteristics that should be held by a good out-of-school learning environment.

Before studies on determining whether out-of-school learning processes have an effect on academic success, interest, attitude, critical thinking, scientific process skills, etc., the extent to which the environment in question is suitable for the approach of out-of-school learning should be determined. Similarly, it should be found out whether the activities in out-of-school learning environments are suitable especially for modern approaches of learning. Otherwise, researchers would study the effects of an environment whose suitability for out-of-school learning processes is unknown on the variables in question, and this will provide incomplete or incorrect results.

On the other hand, considering the importance, effectiveness and necessity out-of-school learning, which is a new approach in science instruction, it is indispensable that the process must be carried out correctly and effectively in terms of science and pedagogy.

In the light of this information, the purpose of this study that we expect will provide a contribution, is to; examine the out-of-school learning environments located in proximity (İzmir provincial borders) using the developed "Out-Of-School Learning Environments Evaluation Survey", and investigate the activities they contain in terms of their suitability for constructivist paradigm, criteria expected from out-of-school learning processes, and physical conditions and fields of learning.

\section{Method}

In this study which aims to examine out-of-school learning environments and the processes and activities they contain in terms of their suitability for constructivist paradigm, criteria expected from out-of-school learning processes, physical conditions and fields of learning, the researchers used the "single screening model", which is a descriptive research method. The purpose of this screening model is to determine the state of an event, phenomenon or object of a certain period at the time of conducting research [23].

\subsection{Population and Sample}

The population of the study consisted of out-of-school learning environments located in Turkey. As the sample, a total of 13 out-of-school learning environments located in İzmir were selected. These included the Young Explorers Center for Science, the Mevlana Center for Science, the Ödemiş Center for Science, Karşıyaka Museum of Science, İzmir Museum of Archeology, Museum of Ethnography, Inciraltı Naval Museum, Arkas Museum of Art, Selçuk Urban Memory, the Ancient City of Efes, Ege University Botanical Garden, and Sasalı Wild Life Park. In selection of the sample of out-of-school learning environments reachable sampling were considered. Sampling was performed in a way to cover different out of school environments (museum, center for science, wild life park, etc.) in order to reflect all informal environment.

The types and numbers of the out-of-school learning environments in the sample are given in Table 1.

Table 1. Characteristics of the out-of-school learning environments included in the sample

\begin{tabular}{|c|c|}
\hline Type of the Learning Environment & Number \\
\hline Science Center & 4 \\
\hline Science Museum & 1 \\
\hline Botanical Gardens and Wild Life Areas & 2 \\
\hline Museum & 5 \\
\hline Ancient City & 1 \\
\hline Total & 13 \\
\hline
\end{tabular}

Table 1 shows that the 13 out-of-school environments included 4 centers for science, 1 science museum, 2 botanical gardens and wild life areas, 5 museums and 1 ancient city. While preparing the measurement tool, is was aimed to evaluate learning areas based on science and different learning areas (museum, ancient city, botanical garden, etc.). Thus, in order to determine whether the measurement tool has this characteristic, sampling was made in historical areas such as museums and ancient cities.

\subsection{Data Collection and Analysis}

The researchers developed the "Out-Of-School Learning Environments Evaluation Survey" used in the study. Using a statistical package software, descriptive statistical operations were performed on the data obtained as a result of the process and based on frequency (f) and percentage (\%) calculations.

\subsection{Data Collection Tools}

The literature review showed that measurement tools used in social sciences are named as "test, survey and inventory" based on various characteristics. Accordingly, measurement tools for determining competence of individuals regarding a skill in a certain time interval were called "tests"; those that are used to determine characteristics of individuals containing sub-categories unrelated to each other such as attitude, personality traits, etc. are called "inventories". Measurement tools that are used to collect data regarding multiple characteristics of individuals, events or places at the same time are called "surveys" [10]. Therefore, the measurement tool developed for determining more than one characteristic of out-of-school learning environments was named the "Out-Of-School Learning Environments Evaluation Survey" (OOSLEES).

In the development process of the measurement tool; firstly, a review of the literature was performed; characteristics of the out-of-school learning processes and environments, and characteristics of teaching process based 
on the constructivist approach were determined, and in this context, a general framework was established regarding the design of out-of-school environments based on the constructivist understanding of learning. The characteristics of out-of-school learning were determined by utilizing the 6 main strands reported by the National Research Council [31] and NFS [32].

Characteristics of constructivist learning and learning environments suitable for this approach were determined by utilizing the works by Brooks and Brooks [5], Fosnot [14], Taylor, Fraser and Fisher [41], and physical properties a learning environment should have been found.

Therefore, 6 main themes were determined for the measurement tool and the sections of the survey were formed based on these themes. The 1st section of the survey aims to determine the description of the learning environment. The 2nd section aims to determine the types and characteristics in the learning environment. The 3 rd section consists of 7 question items that aim to determine the suitability of the content in the learning environment for Constructivist Learning Approach (CLA) based on its type and characteristics. The 4 th section contains 4 question items towards determining the "motivational characteristics" of the out-of-school learning environment. The 5 th section consists of 5 question items towards determining "scientific concept and terminology provision" characteristics. The 6th section consists of 9 questions that aim to determine "characteristics that make participants use scientific reasoning processes". The 7 th section has 8 question items aim to determine "characteristics that make participants reflect on science". The 8th section contains 3 questions towards determining "characteristics that provide skills for usage of scientific language and instruments". The 9th section contains 2 questions that aim to determine "characteristics that make individuals feel as a scientist". The 10th section contains 9 questions that aim to determine the "physical characteristics of the learning environment". Finally, the 11th section consists of 4 question items for an environment's characteristics regarding fields of learning. The measurement tool consists of a total of 11 sections and 51 questions. Additionally, there is a part in each section for observer notes. While grading the measurement tool, "yes" means 2 points, "partly" means 1 point, and "no" means 0 points.

The environments were assessed by three academics who were experts in the field by using the questionnaire.

The sections of the survey as a result of this process, number of questions in these sections, and maximum total scores are given in Table 2.

Based on the average total score in all sections of the survey, $0-35 \%$ indicates "very weak"; $36-50 \%$ indicates "weak"; $51-65 \%$ indicates "acceptable"; $66-84 \%$ indicates "good", and $85-100 \%$ indicates a "very good" performance.

In the development of the measurement tool that was prepared as a survey, after writing down question items and forming the structure, opinions of field experts (three faculty members working on science education) were taken about the structure and language validity of the measurement tool. Necessary adjustments were made based on expert opinions and a pilot implementation was made with participation of three researchers. The pilot study checked the operation of survey's sections and questions. After confirming suitability of question items, the agreement of three researchers who analyzed the data obtained in the pilot implementation was found as $80 \%$. Thus, it was understood that the measurement tool was suitable in terms of validity and reliability. The developed survey is provided in Appendix 1. In the study conducted with the measurement tool described above, the findings regarding the data obtained from the sample are given below.

Table 2. OOSLEES sections, numbers of questions in the sections, and maximum total scores

\begin{tabular}{|c|c|c|}
\hline Sections of the Survey & $\begin{array}{c}\text { Number of } \\
\text { Questions }\end{array}$ & Maximum total score \\
\hline Description of the Out-Of-School Learning Environments & 8 & Descriptive Questions \\
\hline Suitability for the Constructivist Learning Approach (CLA) & 7 & 14 \\
\hline Motivational characteristics & 4 & 10 \\
\hline Scientific concept and terminology provision & 5 & 18 \\
\hline Promotion of usage of scientific reasoning processes & 9 & 16 \\
\hline Reflection on science & 8 & 6 \\
\hline Usage of scientific language and instruments & 3 & 18 \\
\hline Individuals' feeling of being like a scientist & 2 & 8 \\
\hline Physical conditions & 9 & 102 \\
\hline Suitability for fields of learning & 4 & \\
\hline Total & 51 & \\
\hline
\end{tabular}




\section{Findings}

The findings regarding the data obtained from the sample using the survey developed with the aim of evaluating out-of-school learning environments based on various parameters are given below. The characteristics of the target audience of out-of-school learning environments are given in Table 3 .
According to Table 3, it may be seen that museums, ancient cities and other areas (wild life park and botanical garden) appealed to "all ages", while science centers had a target audience of people of age 6-18 and the science museum's target audience was the age group of 4-18.

The characteristics of the target audience of out-of-school learning environments are given in Table 4.

Table 3. Findings regarding the characteristics of the target audience of out-of-school learning environments

\begin{tabular}{|c|c|c|}
\hline \multirow{2}{*}{ Type } & Name & Target Audience (Age) \\
\hline \multirow{3}{*}{ Centers for Science } & Young Explorers Center for Science & $6-18$ years \\
\cline { 2 - 3 } & Mevlana Center for Science & $6-18$ years \\
\cline { 2 - 3 } & Gaziemir Space Camp & $6-18$ years \\
\cline { 2 - 3 } & Ödemiş Center for Science & All ages \\
\hline \multirow{2}{*}{ Science Museum } & Karşıaka Science Museum & $4-18$ years \\
\hline \multirow{3}{*}{ Museum } & Archeology Museum & All ages \\
\cline { 2 - 3 } & Ethnography Museum & All ages \\
\cline { 2 - 3 } & Selçuk Urban Memory & All ages \\
\cline { 2 - 3 } & İnciraltı Naval Museum & All ages \\
\cline { 2 - 3 } & Arkas Art Museum & All ages \\
\hline \multirow{2}{*}{ Ancient City } & Efes Ancient City & All ages \\
\hline \multirow{2}{*}{ Other } & Ege University Botanical Garden & All ages \\
\hline
\end{tabular}

Table 4. The characteristics of the target audience of out-of-school learning environments

\begin{tabular}{|c|c|c|}
\hline Type & Name & Direction \\
\hline \multirow{4}{*}{ Centers for Science } & Young Explorers Center for Science & Instructions - Guidance \\
\cline { 2 - 3 } & Mevlana Center for Science & Instructions - Guidance \\
\cline { 2 - 3 } & Gaziemir Space Camp & Instructions - Guidance \\
\cline { 2 - 3 } & Ödemiş Center for Science & Instructions - Guidance \\
\hline \multirow{2}{*}{ Science Museum } & Karşıaka Science Museum & Instructions - Audio Guide \\
\hline \multirow{4}{*}{ Museum } & Archeology Museum & Instructions \\
\cline { 2 - 3 } & Ethnography Museum & Instructions \\
\cline { 2 - 3 } & Selçuk Urban Memory & Instructions - Guidance \\
\cline { 2 - 3 } & İnciraltı Naval Museum & Instructions \\
\cline { 2 - 3 } & Arkas Art Museum & Instructions \\
\hline \multirow{2}{*}{ Ancient City } & Efes Ancient City & Instructions - Guidance \\
\hline \multirow{2}{*}{ Other } & Ege University Botanical Garden & Instructions \\
\hline
\end{tabular}


Table 4 shows that both instructions and guidance were used to direct participants in centers for science and the science museum, museums generally used ready instructions, the botanical garden provided instructions and guidance, and the wild life park only had instructions. Findings regarding the types of content in the out-of-school learning environments are given in Table 5.

Table 5 shows that all activities provided in centers for science were "shows and interactive experiments", while the science museum additionally provided "instructive games". The type of activities in the Naval Museum, the Botanical Garden and the Wild Life Park was "scientific exhibition". In other learning environments in the museum group, there were activities of "scientific-artistic exhibitions".
The scores given by the researchers in OOSLEES regarding the suitability of the content in the out-of-school environments for CLA are given in Table 6 .

Table 6 shows that, in terms of suitability of the constructive learning approach, the Young Explorers and Ödemiş Centers for Science, and Gaziemir Space Camp got full scores and were on a "very good" level; the Mevlana Center for Science had a "good" level; Karşıyaka Science Museum was found "weak". On the other hand, the Archeology an Ethnography Museums were "very weak", İnciraltı Naval Museum being "weak", and Arkas Art Museum being "acceptable". The Wild Life Park and Botanical Garden environments were also found "acceptable".

Table 5. Findings regarding the types of content in the out-of-school learning environments

\begin{tabular}{|c|c|c|}
\hline \multirow{2}{*}{ Type } & Name & Type of Content \\
\hline \multirow{4}{*}{ Centers for Science } & Young Explorers Center for Science & Show-Interactive Experiment \\
\cline { 2 - 3 } & Mevlana Center for Science & Show-Interactive Experiment \\
\cline { 2 - 3 } & Gaziemir Space Camp & Show-Interactive Experiment \\
\cline { 2 - 3 } & Ödemiş Center for Science & Show-Interactive Experiment \\
\hline \multirow{2}{*}{ Science Museum } & Karşıaka Science Museum & Show-Interactive Experiment / Instructive Games \\
\hline \multirow{3}{*}{ Museum } & Archeology Museum & Scientific- Artistic Exhibition \\
\cline { 2 - 3 } & Ethnography Museum & Scientific- Artistic Exhibition \\
\cline { 2 - 3 } & Selçuk Urban Memory & Scientific- Artistic Exhibition \\
\cline { 2 - 3 } & İnciraltı Naval Museum & Scientific Exhibition \\
\cline { 2 - 3 } & Arkas Art Museum & Scientific- Artistic Exhibition \\
\hline Ancient City & Efes Ancient City & Scientific- Artistic Exhibition \\
\hline \multirow{2}{*}{ Other } & Ege University Botanical Garden & Scientific Exhibition \\
\hline
\end{tabular}

Table 6. Findings about the suitability of content in out-of-school learning environments for the constructivist learning approach (CLA)

\begin{tabular}{|c|c|c|c|c|c|}
\hline \multirow[t]{2}{*}{ Type } & \multirow[t]{2}{*}{ Name } & \multirow[b]{2}{*}{ Score } & \multicolumn{3}{|c|}{ CLA suitability } \\
\hline & & & $\begin{array}{c}\text { Ratio in Maximum } \\
\text { Score }\end{array}$ & $\%$ & Level \\
\hline \multirow{4}{*}{ Centers for Science } & Young Explorers Center for Science & 14 & $14 / 14$ & 100 & Very Good \\
\hline & Mevlana Center for Science & 11 & $11 / 14$ & 78 & Good \\
\hline & Gaziemir Space Camp & 14 & $11 / 14$ & 100 & Very Good \\
\hline & Ödemiş Center for Science & 14 & $14 / 14$ & 100 & Very Good \\
\hline Science Museum & Karşıyaka Science Museum & 6 & $6 / 14$ & 42 & Weak \\
\hline \multirow{5}{*}{ Museum } & Archeology Museum & 5 & $5 / 14$ & 35 & Very Weak \\
\hline & Ethnography Museum & 5 & $5 / 14$ & 35 & Very Weak \\
\hline & Selçuk Urban Memory & 12 & $12 / 14$ & 85 & Very Good \\
\hline & İnciraltı Naval Museum & 6 & $6 / 14$ & 42 & Weak \\
\hline & Arkas Art Museum & 7 & $7 / 14$ & 50 & Acceptable \\
\hline Ancient City & Efes Ancient City & 6 & $6 / 14$ & 42 & Weak \\
\hline \multirow{2}{*}{ Other } & Ege University Botanical Garden & 7 & $7 / 14$ & 50 & Acceptable \\
\hline & Sasalı Wild Life Park & 9 & $9 / 14$ & 64 & Acceptable \\
\hline
\end{tabular}


Findings regarding the scores in OOSLEES for motivational characteristics of out-of-school learning environments are given in Table 7.

Table 7 shows that, in terms of motivation for participants provided by out-of-school learning environments, the centers for science were on a "very good" level; the Karşıyaka Science Museum, the Wild Life Park, Arkas Art Museum, Selçuk Urban Memory and the Naval Museum were on a "good" level; the Archeology and Ethnography Museums, and the Botanical Garden were on an "acceptable" level.
Findings from OOSLEES about characteristics of learning environments towards usage of scientific concepts and terminology are given in Table 8 .

Table 8 shows that, in terms of promotion of usage of scientific concepts and terminology, the Mevlana Center for Science was "good", while the other centers for science were "very good". On the other hand, Karşıyaka Science Museum and Efes Ancient city were "acceptable"; Selçuk Urban Memory was "weak", and the other museums were "very weak". Additionally, the Botanical Garden was "very weak" and the Wild Life Park was "weak".

Table 7. Findings regarding the scores in OOSLEES for motivational characteristics of out-of-school learning environments

\begin{tabular}{|c|c|c|c|c|c|}
\hline \multirow[t]{2}{*}{ Type } & \multirow[t]{2}{*}{ Name } & \multirow[b]{2}{*}{ Score } & \multicolumn{3}{|c|}{ Motivation } \\
\hline & & & $\begin{array}{l}\text { Ratio in Maximum } \\
\text { Score }\end{array}$ & $\%$ & Level \\
\hline \multirow{4}{*}{ Centers for Science } & Young Explorers Center for Science & 8 & $8 / 8$ & 100 & Very Good \\
\hline & Mevlana Center for Science & 7 & $7 / 8$ & 87 & Very Good \\
\hline & Gaziemir Space Camp & 8 & $8 / 8$ & 100 & Very Good \\
\hline & Ödemiş Center for Science & 8 & $8 / 8$ & 100 & Very Good \\
\hline Science Museum & Karşıyaka Science Museum & 6 & $6 / 8$ & 75 & Good \\
\hline \multirow{5}{*}{ Museum } & Archeology Museum & 5 & $5 / 8$ & 63 & Acceptable \\
\hline & Ethnography Museum & 5 & $5 / 8$ & 63 & Acceptable \\
\hline & Selçuk Urban Memory & 6 & $6 / 8$ & 75 & Good \\
\hline & İnciraltı Naval Museum & 6 & $6 / 8$ & 75 & Good \\
\hline & Arkas Art Museum & 6 & $6 / 8$ & 75 & Good \\
\hline Ancient City & Efes Ancient City & 6 & $6 / 8$ & 75 & Good \\
\hline \multirow{2}{*}{ Other } & Ege University Botanical Garden & 5 & $5 / 8$ & 63 & Acceptable \\
\hline & Sasalı Wild Life Park & 6 & $6 / 8$ & 75 & Good \\
\hline
\end{tabular}

Table 8. Findings from OOSLEES about characteristics of learning environments towards usage of scientific concepts and terminology

\begin{tabular}{|c|c|c|c|c|c|}
\hline \multirow{2}{*}{ Type } & Name & \multicolumn{2}{c|}{ Scientific Concept and Terminology } \\
\hline \multirow{4}{*}{ Centers for Science } & & Score & $\begin{array}{c}\text { Ratio in } \\
\text { Maximum Score }\end{array}$ & $\%$ & Level \\
\cline { 2 - 6 } & Young Explorers Center for Science & 9 & $9 / 10$ & 90 & Very Good \\
\cline { 2 - 6 } & Mevlana Center for Science & 8 & $8 / 10$ & 80 & Good \\
\cline { 2 - 6 } & Gaziemir Space Camp & 10 & $10 / 10$ & 100 & Very Good \\
\hline \multirow{2}{*}{ Science Museum } & Ödemiş Center for Science & 10 & $10 / 10$ & 100 & Very Good \\
\hline \multirow{3}{*}{ Museum } & Karşyaka Science Museum & 5 & $5 / 10$ & 50 & Acceptable \\
\cline { 2 - 6 } & Archeology Museum & 2 & $2 / 10$ & 20 & Very Weak \\
\cline { 2 - 6 } & Ethnography Museum & 2 & $2 / 10$ & 20 & Very Weak \\
\cline { 2 - 6 } & Selçuk Urban Memory & 4 & $4 / 10$ & 40 & Weak \\
\cline { 2 - 6 } & İnciraltı Naval Museum & 2 & $2 / 10$ & 20 & Very Weak \\
\hline \multirow{2}{*}{ Ancient City } & Arkas Art Museum & 2 & $2 / 10$ & 20 & Very Weak \\
\hline \multirow{2}{*}{ Other } & Efes Ancient City & 5 & $5 / 10$ & 50 & Acceptable \\
\cline { 2 - 6 } & Ege University Botanical Garden & 2 & $2 / 10$ & 20 & Very Weak \\
\hline
\end{tabular}


Findings from OOSLEES about characteristics of learning environments towards usage of scientific reasoning processes are given in Table 9.

Table 9 shows that, in terms of promotion of usage of scientific reasoning processes, all centers for science were "very good", while all other out-of-school learning environments in the sample were "very week" in terms of this characteristic.
Findings from OOSLEES about characteristics of learning environments towards reflection on science are given in Table 10

Table 10 shows that, in terms of promotion of reflection on science, all centers of science were "very good", while Karşıyaka Science Museum, Sasalı Wild Life Park, Efes Ancient City and Selçuk Urban Memory were "acceptable". Again, the Archeology Museum was "very weak"; the Ethnography, Naval and Art Museums were "weak".

Table 9. Findings from OOSLEES about characteristics of learning environments towards usage of scientific reasoning processes

\begin{tabular}{|c|c|c|c|c|c|}
\hline \multirow[t]{2}{*}{ Type } & \multirow[t]{2}{*}{ Name } & \multirow[b]{2}{*}{ Score } & \multicolumn{3}{|c|}{ Usage of Scientific Reasoning Processes } \\
\hline & & & Ratio in Maximum Score & $\%$ & Level \\
\hline \multirow{4}{*}{ Centers for Science } & Young Explorers Center for Science & 17 & $17 / 18$ & 94 & Very Good \\
\hline & Mevlana Center for Science & 17 & $17 / 18$ & 94 & Very Good \\
\hline & Gaziemir Space Camp & 17 & $17 / 18$ & 94 & Very Good \\
\hline & Ödemiş Center for Science & 17 & $17 / 18$ & 94 & Very Good \\
\hline Science Museum & Karşıyaka Science Museum & 2 & $2 / 18$ & 11 & Very Weak \\
\hline \multirow{5}{*}{ Museum } & Archeology Museum & 1 & $1 / 18$ & 5 & Very Weak \\
\hline & Ethnography Museum & 2 & $2 / 18$ & 11 & Very Weak \\
\hline & Selçuk Urban Memory & 4 & $4 / 18$ & 22 & Very Weak \\
\hline & İnciraltı Naval Museum & 4 & $4 / 18$ & 22 & Very Weak \\
\hline & Arkas Art Museum & 3 & $3 / 18$ & 17 & Very Weak \\
\hline Ancient City & Efes Ancient City & 3 & $3 / 18$ & 17 & Very Weak \\
\hline \multirow{2}{*}{ Other } & Ege University Botanical Garden & 3 & $3 / 18$ & 17 & Very Weak \\
\hline & Sasalı Wild Life Park & 5 & $5 / 18$ & 27 & Very Weak \\
\hline
\end{tabular}

Table 10. Findings from OOSLEES about characteristics of learning environments towards reflection on science

\begin{tabular}{|c|c|c|c|c|c|}
\hline \multirow[t]{2}{*}{ Type } & \multirow[t]{2}{*}{ Name } & \multirow[b]{2}{*}{ Score } & \multicolumn{3}{|c|}{ Reflection on Science } \\
\hline & & & Ratio in Maximum Score & $\%$ & Level \\
\hline \multirow{4}{*}{ Centers for Science } & Young Explorers Center for Science & 14 & $14 / 16$ & 88 & Very Good \\
\hline & Mevlana Center for Science & 15 & $15 / 16$ & 94 & Very Good \\
\hline & Gaziemir Space Camp & 14 & $14 / 16$ & 88 & Very Good \\
\hline & Ödemiş Center for Science & 14 & $14 / 16$ & 88 & Very Good \\
\hline Science Museum & Karşıyaka Science Museum & 4 & $4 / 16$ & 25 & Very Weak \\
\hline \multirow{5}{*}{ Museum } & Archeology Museum & 4 & $4 / 16$ & 25 & Very Weak \\
\hline & Ethnography Museum & 7 & $7 / 16$ & 43 & Weak \\
\hline & Selçuk Urban Memory & 11 & $11 / 16$ & 65 & Acceptable \\
\hline & İnciraltı Naval Museum & 7 & $7 / 16$ & 43 & Weak \\
\hline & Arkas Art Museum & 6 & $6 / 16$ & 38 & Weak \\
\hline Ancient City & Efes Ancient City & 8 & $8 / 16$ & 50 & Acceptable \\
\hline \multirow{2}{*}{ Other } & Ege University Botanical Garden & 5 & $5 / 16$ & 31 & Very Weak \\
\hline & Sasalı Wild Life Park & 10 & $10 / 16$ & 63 & Acceptable \\
\hline
\end{tabular}


Findings from OOSLEES about characteristics of learning environments towards skills for usage of scientific language and instruments are given in Table 11.

Table 11 shows that, in terms of provision of skills for usage of scientific language and instruments, the Mevlana Center for Science and Karşıyaka Science Museum were "good", while the other centers for science were "very good". On the other hand, the museums, Efes Ancient City, the Wild Life Park and the Botanical Garden were found "very weak". OOSLEES findings regarding the characteristics of the sampled learning environments that make participants feel like scientists are given in Table 12.

Table 12 shows that, in terms of making participants feel like scientists, the centers for science were "very good", while Karşıyaka Science Museum, the Archeology Museum, the Ethnography Museum, Selçuk Urban Memory, the Botanical Garden and the Wild Life Park were "acceptable". On the other hand, İnciraltı Naval Museum and Arkas Art Museum were "good", while the ancient city of Efes was "very weak".

Table 11. Findings from OOSLEES about characteristics of learning environments towards skills for usage of scientific language and instruments

\begin{tabular}{|c|c|c|c|c|c|}
\hline \multirow[t]{2}{*}{ Type } & \multirow[t]{2}{*}{ Name } & \multirow[b]{2}{*}{ Score } & \multicolumn{3}{|c|}{ Usage of Scientific Language and Instruments } \\
\hline & & & Ratio in Maximum Score & $\%$ & Level \\
\hline \multirow{4}{*}{ Centers for Science } & Young Explorers Center for Science & 6 & $6 / 6$ & 100 & Very Good \\
\hline & Mevlana Center for Science & 5 & $5 / 6$ & 84 & Good \\
\hline & Gaziemir Space Camp & 6 & $6 / 6$ & 100 & Very Good \\
\hline & Ödemiş Center for Science & 6 & $6 / 6$ & 100 & Very Good \\
\hline Science Museum & Karşıyaka Science Museum & 4 & $4 / 6$ & 67 & Good \\
\hline \multirow{5}{*}{ Museum } & Archeology Museum & 1 & $1 / 6$ & 16 & Very Weak \\
\hline & Ethnography Museum & 1 & $1 / 6$ & 16 & Very Weak \\
\hline & Selçuk Urban Memory & 1 & $1 / 6$ & 16 & Very Weak \\
\hline & İnciraltı Naval Museum & 2 & $2 / 6$ & 32 & Very Weak \\
\hline & Arkas Art Museum & 1 & $1 / 6$ & 16 & Very Weak \\
\hline Ancient City & Efes Ancient City & 1 & $1 / 6$ & 16 & Very Weak \\
\hline \multirow{2}{*}{ Other } & Ege University Botanical Garden & 1 & $1 / 6$ & 16 & Very Weak \\
\hline & Sasalı Wild Life Park & 1 & $1 / 6$ & 16 & Very Weak \\
\hline
\end{tabular}

Table 12. OOSLEES findings regarding the characteristics of the sampled learning environments that make participants feel like scientists

\begin{tabular}{|c|c|c|c|c|c|}
\hline \multirow[t]{2}{*}{ Type } & \multirow[t]{2}{*}{ Name } & \multirow[b]{2}{*}{ Score } & \multicolumn{3}{|c|}{ Feeling Like a Scientist } \\
\hline & & & Ratio in Maximum Score & $\%$ & Level \\
\hline \multirow{4}{*}{ Centers for Science } & Young Explorers Center for Science & 4 & $4 / 4$ & 100 & Very Good \\
\hline & Mevlana Center for Science & 4 & $4 / 4$ & 100 & Very Good \\
\hline & Gaziemir Space Camp & 4 & $4 / 4$ & 100 & Very Good \\
\hline & Ödemiş Center for Science & 4 & $4 / 4$ & 100 & Very Good \\
\hline Science Museum & Karşıyaka Science Museum & 2 & $2 / 4$ & 50 & Acceptable \\
\hline \multirow{5}{*}{ Museum } & Archeology Museum & 2 & $2 / 4$ & 50 & Acceptable \\
\hline & Ethnography Museum & 2 & $2 / 4$ & 50 & Acceptable \\
\hline & Selçuk Urban Memory & 2 & $2 / 4$ & 50 & Acceptable \\
\hline & İnciraltı Naval Museum & 3 & $3 / 4$ & 75 & Good \\
\hline & Arkas Art Museum & 3 & $3 / 4$ & 75 & Good \\
\hline Ancient City & Efes Ancient City & 1 & $1 / 4$ & 25 & Very Weak \\
\hline \multirow{2}{*}{ Other } & Ege University Botanical Garden & 2 & $2 / 4$ & 50 & Acceptable \\
\hline & Sasalı Wild Life Park & 2 & $2 / 4$ & 50 & Acceptable \\
\hline
\end{tabular}


OOSLEES findings regarding the physical conditions in the investigated learning environments are given in Table 13.

In terms of physical conditions of the sampled learning environments, Table 13 shows that the Mevlana Center for Science was found "good", while the other centers for science were "very good". Additionally, the Wild Life Park, the Science Museum, the Archeology Museum, the Naval Museum and the Art Museum were found "very good". On the other hand, the Ethnography Museum and the Botanical Garden were found "acceptable", while the ancient city of
Efes was "good".

Findings regarding the suitability of out-of-school learning environment for fields of learning are given in Table 14.

Table 14 shows that, in terms of suitability for fields of learning (cognitive, sensory and psychomotor), the Mevlana Center for Science and Karşıyaka Science Museum were "good"; the other centers for science were "very good". On the other hand, the ancient city of Efes was found "weak", while the remaining environments were "acceptable".

Table 13. OOSLEES findings regarding the physical conditions in learning environments

\begin{tabular}{|c|c|c|c|c|c|}
\hline \multirow[t]{2}{*}{ Type } & \multirow[t]{2}{*}{ Name } & \multirow[b]{2}{*}{ Score } & \multicolumn{3}{|c|}{ Physical Conditions } \\
\hline & & & $\begin{array}{c}\text { Ratio in } \\
\text { Maximum Score }\end{array}$ & $\%$ & Level \\
\hline \multirow{4}{*}{ Centers for Science } & Young Explorers Center for Science & 16 & $16 / 18$ & 88 & Very Good \\
\hline & Mevlana Center for Science & 14 & $14 / 18$ & 78 & Good \\
\hline & Gaziemir Space Camp & 16 & $16 / 18$ & 88 & Very Good \\
\hline & Ödemiş Center for Science & 15 & $15 / 18$ & 85 & Very Good \\
\hline Science Museum & Karşıyaka Science Museum & 14 & $14 / 18$ & 85 & Very Good \\
\hline \multirow{5}{*}{ Museum } & Archeology Museum & 16 & $16 / 18$ & 88 & Very Good \\
\hline & Ethnography Museum & 10 & $10 / 18$ & 56 & Acceptable \\
\hline & Selçuk Urban Memory & 10 & $10 / 18$ & 56 & Acceptable \\
\hline & İnciraltı Naval Museum & 15 & $15 / 18$ & 85 & Very Good \\
\hline & Arkas Art Museum & 15 & $15 / 18$ & 85 & Very Good \\
\hline Ancient City & Efes Ancient City & 12 & $12 / 18$ & 67 & Good \\
\hline \multirow{2}{*}{ Other } & Ege University Botanical Garden & 10 & $10 / 18$ & 56 & Acceptable \\
\hline & Sasalı Wild Life Park & 15 & $15 / 18$ & 85 & Very Good \\
\hline
\end{tabular}

Table 14. Findings regarding the suitability of out-of-school learning environment for fields of learning

\begin{tabular}{|c|c|c|c|c|c|}
\hline \multirow{2}{*}{ Type } & Name & \multicolumn{2}{|c|}{ Suitability for Fields of Learning } \\
\hline \multirow{4}{*}{ Centers for Science } & & Score & $\begin{array}{c}\text { Ratio in } \\
\text { Maximum Score }\end{array}$ & $\%$ & Level \\
\cline { 2 - 6 } & Young Explorers Center for Science & 8 & $8 / 8$ & 100 & Very Good \\
\cline { 2 - 6 } & Mevlana Center for Science & 6 & $6 / 8$ & 75 & Good \\
\cline { 2 - 6 } & Gaziemir Space Camp & 8 & $8 / 8$ & 100 & Very Good \\
\hline \multirow{2}{*}{ Science Museum } & Ödemiş Center for Science & 8 & $8 / 8$ & 100 & Very Good \\
\hline \multirow{3}{*}{ Museum } & Karşıaka Science Museum & 6 & $6 / 8$ & 75 & Good \\
\cline { 2 - 6 } & Archeology Museum & 4 & $4 / 8$ & 50 & Acceptable \\
\cline { 2 - 6 } & Ethnography Museum & 4 & $4 / 8$ & 50 & Acceptable \\
\cline { 2 - 6 } & Selçuk Urban Memory & 4 & $4 / 8$ & 50 & Acceptable \\
\cline { 2 - 6 } & İnciraltı Naval Museum & 5 & $5 / 8$ & 63 & Acceptable \\
\hline \multirow{2}{*}{ Ancient City } & Arkas Art Museum & 4 & $4 / 8$ & 50 & Acceptable \\
\hline \multirow{2}{*}{ Other } & Efes Ancient City & 3 & $3 / 8$ & 38 & Weak \\
\cline { 2 - 6 } & Ege University Botanical Garden & 4 & $4 / 8$ & 50 & Acceptable \\
\cline { 2 - 6 } & Sasalı Wild Life Park & 4 & $4 / 8$ & 50 & Acceptable \\
\hline
\end{tabular}


Table 15. Findings regarding the total scores of the sampled learning environments

\begin{tabular}{|c|c|c|c|c|c|}
\hline \multirow{2}{*}{ Type } & Name & \multicolumn{3}{|c|}{ Total Scores } \\
\hline \multirow{4}{*}{ Centers for Science } & & Score & $\begin{array}{c}\text { Ratio in Maximum } \\
\text { Score }\end{array}$ & $\%$ & Level \\
\cline { 2 - 6 } & Young Explorers Center for Science & 96 & $96 / 102$ & 95 & Very Good \\
\cline { 2 - 6 } & Mevlana Center for Science & 87 & $87 / 102$ & 85 & Very Good \\
\cline { 2 - 7 } & Gaziemir Space Camp & 97 & $97 / 102$ & 96 & Very Good \\
\hline \multirow{2}{*}{ Science Museum } & Ödemiş Center for Science & 96 & $96 / 102$ & 95 & Very Good \\
\hline \multirow{3}{*}{ Museum } & Karşiyaka Science Museum & 48 & $48 / 102$ & 47 & Weak \\
\cline { 2 - 7 } & Archeology Museum & 41 & $48 / 102$ & 40 & Weak \\
\cline { 2 - 7 } & Ethnography Museum & 44 & $44 / 102$ & 43 & Weak \\
\cline { 2 - 7 } & Selçuk Urban Memory & 54 & $54 / 102$ & 53 & Acceptable \\
\cline { 2 - 7 } & Inciraltı Naval Museum & 47 & $47 / 102$ & 46 & Weak \\
\hline \multirow{2}{*}{ Ancient City } & Arkas Art Museum & 46 & $46 / 102$ & 45 & Weak \\
\hline \multirow{2}{*}{ Other } & Efes Ancient City & 51 & $51 / 102$ & 50 & Acceptable \\
\cline { 2 - 6 } & Ege University Botanical Garden & 58 & $58 / 102$ & 57 & Acceptable \\
\hline
\end{tabular}

Findings regarding the total scores of the sampled learning environments are given in Table 15.

Table 15 shows that, in terms of the total scores in the evaluation process, the centers for science were found "very good", while the Science, Archeology, Ethnography, Naval and Art Museums were "weak". Additionally, Urban Memory, Efes Ancient City, the Botanical Garden and the Wild Life Park were found "acceptable".

\section{Discussion and Conclusions}

It may be stated that noteworthy results were reached in this study, where the purpose was to evaluate out-of-school learning environments.

According to the findings as a result of the research process, it was seen that centers for science generally addressed people of a 6 to 18, while the Science Museum appealed to people of age from 4 to 18 . On the other hand, other evaluated learning environments (museums, ancient, city, botanical garden and wild life park) addressed people of "all ages" (Table 3). Considering the characteristics of out-of-school learning, it has been emphasized that a learning environment, processes in the environment, and included content should have the quality to include people of all ages in the process $[2,9,19,21,30]$. Therefore, it was observed that the Museum, the Ancient City, the Botanical Garden and the Wild Life Park among the sampled environments carried this quality, while the Science Museum and the Centers for Science were limited in terms of their target audience. Accordingly, it may be suggested that the Centers for Science and the Science Museum should be improved in terms of their target audience.

On the other hand, looking at the methods used in these environments for directing participants, all Centers for
Science and the Science Museum provided both "guidance service" and "instructions". It was found that all learning environments in the museum group had "instructions"; the Archeology Museum had "audio guide"; Ínciraltı Naval Museum had guidance service. The Wild Life Park only had instructions, while the Botanical Garden had both instructions and guidance (Table 4). Considering that there is no fixed plan in out-of-school learning environments and participants try to construct information in this process without a teacher, it may be seen that appropriate guidance is needed in such environments and it is crucial that instructions with scientific qualities are present in the content and activities of these environments $[12,28]$. Therefore, it is seen that the Ethnography Museum, Selçuk Urban Memory, Arkas Art Museum, Efes Ancient City and Sasalı Wild Life Park had shortcomings in terms of "guidance service" and they should be supported in this sense. Again, in order to prevent participants from misconceptions and support them in meaningful construction of information, persons providing the guidance service should be experts in the field and instructions should be prepared in a way that is suitable for scientific information and processes.

Considering the findings regarding the types of content in out-of-school learning environments, it was found that the types of activities and content provided in Centers for Science were "shows or interactive experiments", while the Science Museum provided "instructive games" in addition to these. Inciraltı Naval Museum provided only "scientific exhibitions", while other museums (Archeology, Ethnography and City Memory) and the ancient city of Efes provided "artistic exhibitions" in addition to "scientific" ones. The Botanical Garden and the Wild Life Park had content in the form of "scientific exhibitions" (Table 5). If we consider the subject in terms of the constructivist learning approach and characteristics of out-of-school learning, 
construction of information in a more permanent and meaningful way may be achieved by the presence of activities and content that will facilitate active participation of the individual in the learning process $[14,17,41]$. On the other hand, achieving motivation and high levels of it in the out-of-school learning process, again, is possible by active participation of the individual in the learning process [3, 7, 12]. In this sense, it was seen that, while active participation of individuals was achieved by the presence of interactive experiments in Centers for Science, there were no activities that would motivate participants (instructive games, games for adults, etc. Accordingly, it may be argued that these centers should be improved in this sense. As the Science Museum had both games that provide motivation and those that ensure active participation, it had the desired qualities. On the other hand, the museum group, the Ancient City, the Botanical Garden and the Wild Life Park only had activities in form of exhibitions and therefore, participants stayed passive in the process. It may be suggested that these environments should include activities that involve the individual in the process where the information is constructed by the participant, as well as instructional games and applications that will motivate participants.

According to the findings regarding the suitability of learning environments for the Constructivist Learning Approach (CLA), the Mevlana Center for Science was "good"; the other centers for science and Urban Memory were "very good"; the Science and Naval Museums were "weak"; the Archeology and Ethnography Museums were "very weak"; the Art Museum, the Botanical Garden and the Wild Life Park were "acceptable" (Table 6). Considering that processes are much more meaningful and motivating for individuals with the new and significant point of view brought by the constructivist approach into the process of learning and teaching, it may be argued that out-of-school learning environments should comply with this approach in all aspects [5,17,20,21]. Thus, environments that have shortcomings about compliance with the constructivist approach (environments outside the centers for science) may be reshaped in the light of this approach.

Considering the findings regarding the motivational characteristics of out-of-school learning environment, the centers for science were on a "very good" level; the Karşıyaka Science Museum, the Wild Life Park, Arkas Art Museum, Selçuk Urban Memory and the Naval Museum were on a "good" level; the Archeology and Ethnography Museums, and the Botanical Garden were on an "acceptable" level (Table 7). The most important aspects of out-of-school learning processes which are more beneficial than other processes is that individuals have higher levels of motivation $[37,38]$. Accordingly, the need arises for effectively employing processes and content that will motivate the participants. Therefore, it is recommended that places that were found "acceptable" for this matter, and the Archeology and Ethnography Museums and the Botanical Garden should use reorganization performed by utilization of motivation strategies.

Considering the findings on promotion of usage of scientific concepts and terminology; the Mevlana Center for Science was "good", while the other centers for science were "very good". On the other hand, Karşıyaka Science Museum and Efes Ancient city were "acceptable"; Selçuk Urban Memory was "weak", and the other museums were "very weak". Additionally, the Botanical Garden was "very weak" and the Wild Life Park was "weak" (Table 8). In learning environments, one of the indicators that individuals structure the information presented in content permanently and meaningfully is their skills in usage of relevant scientific concepts and terminology $[17,20]$. In this sense, the process and content presented in out-of-school learning environments should provide individuals with skills to use these concepts and terminology. It was seen that, among the evaluated learning environments, all but the Centers for Science failed to comply with this criterion. Therefore, it may be stated that these environments should be improved in this aspect or redesigned.

Considering the findings regarding participants' usage of scientific reasoning processes in learning environments, the Centers for Science were "very good", while other environments were "very weak" (Table 9). While scientific reasoning processes vary based on types of scientific fields, it is asserted that their importance for each branch of science is undeniable $[8,26,29,40]$. In this sense, transformation of out-of-school learning environments into places where learning takes place permanently and meaningfully by separating them from trip-based environments, may become possible by these environments encourage individuals to structure information by using scientific reasoning processes. The fact that all environments but the Centers for Science were lacking in this aspect may be an indicator that these were designed for tourism reasons. These environments should be reorganized in order to carry out learning processes meaningfully and effectively.

Considering the findings in terms of promotion of reflection on science, all centers of science were "very good", while Karşıyaka Science Museum, Sasalı Wild Life Park, Efes Ancient City and Selçuk Urban Memory were "acceptable". Again, the Archeology Museum was "very weak", but the Ethnography, Naval and Art Museums were "weak" (Table 10). Thinking that the concept of reflecting on science means "the usage of structured information in other areas," its importance for the learning process is undeniable $[21,28,32]$. Accordingly, all places other than Centers for Science were lacking in this aspect, and improvements should be made or these places should be reorganized to keep this aspect in mind.

Considering the findings regarding provision of skills for usage of scientific language and instruments, the Mevlana Center for Science and Karşıyaka Science Museum were "good", while the other centers for science were "very good". On the other hand, the museums, Efes Ancient City, the Wild Life Park and the Botanical Garden were found "very weak 
(Table 11). It is reported that, in out-of-school learning processes, level of learning (application step) may be increased by active participation of the individuals, and their usage of necessary instruments (laboratory material, camping material, etc.) and language $[12,28]$. Therefore, in order for higher learning to take place in out-of-school learning processes, opportunities should be provided for participants to use the instruments and scientific language required for the relevant field. In this sense, while the Centers for Science and the Science Museum were "adequate" in this matter, other environments were inadequate by a "very weak" level, and they should be either improved or restructured to keep this aspect in mind.

The findings regarding making participants feel like scientists suggest that the centers for science were "very good", while Karşıyaka Science Museum, the Archeology Museum, the Ethnography Museum, Selçuk Urban Memory, the Botanical Garden and the Wild Life Park were "acceptable". On the other hand, Inciraltı Naval Museum and Arkas Art Museum were "good", while the ancient city of Efes was "very weak" (Table 12). In addition to structuring of information by individuals in in-school and out-of-school learning processes, the fundamental purposes of these learning processes include that they are able to think like a scientist (creative, critical, etc.) and understand they may contribute to science by using scientific processes themselves [21, 35]. Accordingly, the learning environments lacking in this aspect should be either improved in this matter or redesigned considering this issue.

Considering the findings about physical conditions, the Mevlana Center for Science was found "good", while the other centers for science were "very good". Additionally, the Wild Life Park, the Science Museum, the Archeology Museum, the Naval Museum and the Art Museum were found "very good". On the other hand, the Ethnography Museum and the Botanical Garden were found "acceptable", while the ancient city of Efes was "good" (Table 13). It is an unquestionable fact that the physical conditions of a learning environment are crucial for a quality and safe process [32]. Therefore, improvements should be made in environments where physical conditions (safety, transportation, building structure, etc.) are not in a desired state.

In terms of suitability for fields of learning (cognitive, sensory and psychomotor), the Mevlana Center for Science and Karşıyaka Science Museum were "good", while the other centers for science were "very good". On the other hand, the ancient city of Efes was found "weak", while the remaining environments were "acceptable". It is emphasized that suitability of processes and content for fields of learning is highly important for high levels of structuring of information by individuals, development of positive attitudes regarding the process, and developing psychomotor skills regarding the structured information [34]. Thus, learning environments lacking this aspect are considered to need improvements accordingly.

In terms of the total scores in the evaluation process, the centers for science were found "very good", while the Science, Archeology, Ethnography, Naval and Art Museums were "weak". Additionally, Urban Memory, Efes Ancient City, the Botanical Garden and the Wild Life Park were found "acceptable" (Table 15). In order to reach desired adequacy of learning environments, there is a need for improvements in characteristics mentioned above, or reorganization by keeping these characteristics in mind.

Consequently, as a result of the research process, it was found that Centers for Science demonstrated desired qualities, while Museums, the Ancient City, the Botanical Garden and the Wild Life Park were not on par in many aspects. This situation, which may seem expected at a first glance, is contrary to the nature of out-of-school learning. All kinds of environments contributing to the out-of-school learning process (museums, centers of science, camps, trips, etc.) should be designed while keeping in mind the nature of the field of science and learning-teaching approaches in addition to being places to visit or have fun in, and they should be environments where information is structured in a persistent and meaningful way. In the opposite case, these environments are not learning environments, but merely places to visit. Additionally, structuring of information in these environments without a teacher or a fixed teaching plan may lead the way to misconceptions and wrong attitudes towards a field of study. This shows that, in out-of-school learning processes, the learning environment should be structured very carefully by considering the qualities mentioned above.

On the other hand, it may be seen that the environments of concern in this study cover various fields of science. For example, the Museum group and the Ancient City are related to History, Art, Archeology, Military Sciences, Natural Sciences, while Centers for Science, the Botanical Garden and the Wild Life Park are related to Natural Sciences (Physics, Chemistry, Biology). Therefore, instead of approaching these environments in a uniform manner, they should be designed by considering the nature of the field of science they appeal to and characteristics of out-of-school learning environments.

The review of the literature revealed that there are several studies on out-of-school learning and its processes, and these studies were conducted to investigate the effects of processes on various parameters (parameters related to cognitive and sensory fields) $[4,11,18,24,36,44]$. On the other hand, there are no studies on how to design an out-of-school learning environment in a way that is the most suitable for the field it is supposed to be related to, which characteristics activities in this environment should have, or which methods are to be used to present such activities. Hence, the following recommendations may be provided for future studies.

\section{Recommendations}

Considering that there is a very wide spectrum of 
out-of-school learning environments and activities in these environments (professional training courses, summer camps, nature and historical site visits, TV, internet, museums, science cafes, etc.), a limitation of the study was the selection of out-of-school environments designed as a sample in the study, and the study covered learning environments located within the borders of the province of İzmir.

The fact that the environments sampled in the study were located within İzmir limits the generalizability of the study. In this sense, different types of out-of-school learning environments in different regions may be investigated.

Studies may be conducted on ways to design learning environments such as museums and ancient cities, wild life parks and botanical gardens in a way that reflects out-of-school learning processes the best.

Moreover, studies may be conducted on which activities the sampled learning environments should include for more effective and meaningful learning processes, as well as the design of these activities.

\section{REFERENCES}

[1] Aydın, C. H. Açık ve uzaktan öğrenme: öğrenci adaylarının bakış açısı. Ankara: İş kur Matbaacılık. 2011.

[2] Batsleer, J. Informal Learning in Youth Work. London: Sage. 2008.

[3] Bell, P., Tzou, C., Bricker, L., \& Baines, A. D. Learning in diversities of structures of social practice: Accounting for how, why and where people learn science. Human Development, 55(5-6), 269-284. 2013.

[4] Bozdoğan, A. E., \& Yalçın, N. (2006). Bilim Merkezlerinin İlköğretim Öğrencilerinin Fene Karşı İlgi Düzeylerinin Değişmesine ve Akademik Başarılarına Etkisi: Enerji Parkı1. Ege Üniversitesi Eğitim Fakültesi Dergisi.

[5] Brooks, J. G. \& Brooks, M. G. In search of understanding: The case for constructivist classrooms. Upper Saddle River, NJ: Merrill Prentice Hall. 1993.

[6] Cropley, A.J. \& Dave, R.H. Lifelong education and the training of teachers. Pergamon, Oxford. 1978.

[7] Cross, J. Informal Learning: Rediscovering the Natural Pathways That Inspire Innovation and Performance. San Francisco: Jossey-Bass. 2006

[8] Driver, R., Asoko, H., Leach, J., Scott, P., \& Mortimer, E. Constructing scientific knowledge in the classroom. Educational researcher, 23(7), 5-12.1994.

[9] Eraut, M. 'Non-formal learning, implicit learning and tacit knowledge in professional work' in F. Coffield The Necessity of Informal Learning, Bristol: The Policy Press. 2000.

[10] Erkuş, A. Psikometrik terimlerin türkçe karşılıklarının anlamları ile yapılan işlemlerin uyuşmazlığı. Eğitimde ve Psikolojide Ölçme ve Değerlendirme Dergisi, 1(2), 72-77. 2010 .
[11] Ertas, H., \& Parmaksızoğlu, A. Okul Dıș1 Bilimsel Etkinliklerin 9. Sınıf Öğrencilerinin Enerji Konusunu Günlük Hayatla İlişkilendirme Düzeyine Etkisi. Necatibey Eğitim Fakültesi Elektronik Fen ve Matematik Eğitimi Dergisi, 5(2). 2011.

[12] Feder, M. A., Shouse, A. W., Lewenstein, B., \& Bell, P. (Eds.). Learning Science in Informal Environments: People, Places, and Pursuits. National Academies Press. 2009.

[13] Fidan, N. Okulda öğrenme ve öğretme. Gül Yayınevi. 1986.

[14] Fosnot, C.T. Constructivism: A psychological theory of learning. In C.T. Fosnot (Ed.). Constructivism: Theory, perspectives and practice (pp. 8-33). New York: Teacher College Press. 1996.

[15] Gagne, R. The Conditions of Learning and Theory of Instruction Robert Gagné. New York, NY: Holt, Rinehart and Winston. 1985

[16] Garrick, J. Informal Learning in the Workplace, London: Routledge. 1997.

[17] Glasersfeld, E. V. Constructivism in education. The international encyclopedia of education, 1, 162-163. 1989.

[18] Harju, V., Pehkonen, L., \& Niemi, H. Serious but fun, self-directed yet social: blogging as a form of lifelong learning. International Journal of Lifelong Education, 1-16. 2016.

[19] Hirsch, S. Teacher Training at Cambridge: Cambridge University Press. 2009.

[20] Hove, K. R. \& Berv, J. Constructing constructivism, epistemological and pedagogical. In D.C. Philips (Ed.). Constructivism in education (pp. 19-40). Chicago; IL: University of Chicago Press. 2000.

[21] Jeffs, T. \& Smith, M. (1990) (eds.) Using Informal Education, Buckingham: Open University Press.

[22] Jonassen, D. H. (1999). Designing constructivist learning environments. In C. M. Reigeluth, (Eds.), Instructional- design theories and models, A new paradigm of instructional theory, Volume II (pp. 215 - 239). New Jersey: Lawrence Erlbaum Associates, Publishers.

[23] Karasar, N. Bilimsel araştırma yöntemi. Ankara: Nobel. 2008.

[24] Kanhadilok, P., \& Watts, M. (2014). Adult play-learning: Observing informal family education at a science museum. Studies in the Education of Adults, 46(1), 23-41.

[25] Kulalıgil, A. Sınıf dışı öğrenme ortamlarında gerçekleşen öğretim uygulamalarının 5. sınıf fen bilimleri dersinde öğrencilerinin akademik başarı, yaratıcılık ve motivasyonlarına etkisi. Yayınlanmamış Yüksek Lisans Tezi, Pamukkale Üniversitesi Eğitim Bilimleri Enstitüsü. 2016.

[26] Kuhn, D. Science as argument: Implications for teaching and learning scientific thinking. Science education, 77(3), 319-337. 1993.

[27] Kurtuluş, A.” İnformal (sınıf dış1) Öğrenme Ortamı pi Günü: Büyük Risk Yarışması Örneği”. Journal of Research in Education and Teaching. Cilt: 4 Sayı: 1.2015.

[28] Laal, M., \& Salamati, P. Lifelong learning; Why do we need it? Procedia-Social and Behavioral Sciences, 31, 399-403. 2012. 
[29] Lavoie, D. R. Effects of Emphasizing Hypothetico Predictive Reasoning within the Science Learning Cycle on High School Student's Process Skills and Conceptual Understandings in Biology. Journal of Research in Science Teaching, 36(10), 1127-1147. 1999.

[30] Maulucc1, M. S. R., \& Brotman, J. S. Teaching science in the city: Exploring linkages between teacher learning and student learning across formal and informal contexts. The New Educator, 6(3-4), 196-211. 2010.

[31] National Research Council. Introduction. Chapters 1 and 2 in Committee on Learning Science in Informal Environments, Learning Science in Informal Environments: People, Places, and Pursuits. P. Bell, B. Lewenstein, A.W. Shouse, and M.A. Feder (Eds.). Center for Education, Division of Behavioral and Social Sciences and Education. Washington, DC: The National Academies Press. 2009.

[32] National Science Foundation. (2011). Informal Science Education (ISE)" Available: http://www.nsf.gov/pubs Erişim: 15.06.2016

[33] Nunan, D. (1996). The Self Directed Teacher: Managing the Learning Process. Cambridge: Cambridge University Press. 1996.

[34] Özden, Y. Öğrenme ve öğretme. Pegem A Yay. Ankara. 2003.

[35] Patrick, W. Recognising non-formal and informal learning outcomes, policies and practices: Outcomes, policies and practices (Vol. 2009, No. 35). OECD publishing. 2010.

[36] Riedinger, K. Identity Development of Youth during Participation at an Informal Science Education Camp. International Journal of Environmental \& Science Education, 10(3). 2015.
[37] Richardson, L. D., \& Wolfe, M. Principles and practice of informal education: Learning through life. Psychology Press. 2001.

[38] Schweingruber, H. A., \& Fenichel, M. Surrounded by Science:: Learning Science in Informal Environments. National Academies Press. 2010.

[39] Stein, A., \& Rosenfeld, S. Bridging the Gap Between Formal and Informal Science Learning. Studies in Science Education, 28 (1996) 87-112.

[40] Saban, A. Öğrenme-Öğretme Süreci. Yeni Teori ve Yaklaşımlar. Üçüncü Baskı.Ankara: Gazi Kitabevi. 2004.

[41] Taylor, P.C., Fraser, B.J., \& Fisher, D.L. Monitoring constructivist learning environment. International Journal of Educational Research, 27 (2), 293-302. 1997.

[42] Tennant, M. 'Is learning transferable?' in D. Boud and J. Garrick (eds.) Understanding Learning at Work, London: Routledge. 1999.

[43] Toprak, M., \& Erdogan, A. Yaşamboyu Öğrenme: Kavram, Politika, Araçlar ve Uygulama (Lifelong Learning: Concept, Policy, Instruments and Implementation). Journal of Higher Education and Science, 2(2). 2012.

[44] Yoon, S. A., Elinich, K., Wang, J., Schooneveld, J. B., \& Anderson, E. Scaffolding informal learning in science museums: How much is too much? Science Education, 97(6), 848-877. 2013. 